\title{
Synthesis of Biphasic Calcium Phosphate by Hydrothermal Route and Conversion to Porous Sintered Scaffold
}

\author{
Sunarso $^{1}$, Ahmad Fauzi Mohd Noor ${ }^{1}$, Shah Rizal Kasim ${ }^{1}$, Radzali Othman ${ }^{1}$, Ika Dewi Ana ${ }^{2}$, \\ Kunio Ishikawa ${ }^{3}$ \\ ${ }^{1}$ School of Materials and Mineral Resources Engineering, Universiti Sains Malaysia, Penang, Malaysia; ${ }^{2}$ Department of Biomedical \\ Sciences and Technology, Faculty of Dentistry, Universitas Gadjah Mada, Yogyakarta, Indonesia; ${ }^{3}$ Department of Biomaterials, \\ Faculty of Dental Science, Kyushu University, Fukuoka, Japan. \\ Email: afauzi@eng.usm.my
}

Received November 22 ${ }^{\text {nd }}, 2012$; revised March 20 ${ }^{\text {th }}, 2013$; accepted April $5^{\text {th }}, 2013$

Copyright (C) 2013 Sunarso et al. This is an open access article distributed under the Creative Commons Attribution License, which permits unrestricted use, distribution, and reproduction in any medium, provided the original work is properly cited.

\begin{abstract}
Biphasic calcium phosphate (BCP) consisting of hydroxyapatite (HA) and $\beta$-tricalcium phosphate ( $\beta$-TCP) was successfully synthesized by new hydrothermal route using $\beta$-TCP as precursor. The X-ray diffraction analysis of as-synthesized powder indicated that $\beta$-TCP had been transformed into HA phase and amount of HA formed gradually increased with prolonged time. The results revealed that the recent technique may be able to control the composition of the obtained BCP which would influence the bioresorbability. Porous body of BCP was prepared by impregnation of polymeric sponge template with the slurry of the powder followed by sintering. The $\mathrm{X}$-ray diffraction of porous product revealed that the composition of $\beta$-TCP increased after sintering indicating that HA had been decomposed. Porous BCP obtained from the recent technique possessed both macro and micropores structure which are useful for rapid tissue formation. Besides, the recent porous fabrication technique yielded porous BCP which preserved the sponge template morphology, enabling it to fabricate porous material with controlled pores structure.
\end{abstract}

Keywords: Biphasic; Calcium Phosphate; $\beta$-TCP; Hydroxyapatite; Hydrothermal; Porous

\section{Introduction}

Biphasic calcium phosphate (BCP), particularly hydroxyapatite (HA) and beta tricalcium phosphate $(\beta$-TCP) is the one that has been extensively investigated [1-3]. The HA ceramics, despite being considered as the ideal material for bone substitute due to its similarity with the bone mineral and osteoconductive property, it is non-resorbable and bio-inert due to its less soluble nature in aqueous media [4], while $\beta$-TCP showed rapid biodegradation [5]. Therefore, a combination of HA with $\beta$-TCP will provide osteoconductive material with higher reactivity and better biodegradation.

Various preparation techniques have been developed to produce BCP powders such as powder mixing [6], solid-state reaction [7] and decomposition reaction [8]. In this study, however, a simple hydrothermal route has been used to prepare BCP powder using $\beta$-TCP as the precursor which allows controlled phase composition. The $\beta$ TCP compound has been reported to be able to completely transform into HA phase under hydrothermal condition [9]. Therefore, biphasic HA/ $\beta$-TCP could be pre- pared by incomplete transformation of $\beta$-TCP compound under hydrothermal condition.

Natural bone has interconnected porous structure necessary for tissue ingrowth, nutrient supply as well as tissue invasion during bone repairing process [10]. The ideal bone substitute material must possess properties that are close to that of natural bone. A porous ceramics structure particularly composed of biphasic BCP hence, is considered as an ideal material for bone substitute.

\section{Materials and Methods}

\subsection{Synthesis of BCP Powder}

To synthesize BCP powder by hydrothermal technique, 5 $\mathrm{g}$ of $\beta$-TCP powder was dispersed with $500 \mathrm{~mL}$ of deionized water. The mixture then was stirred for $1 \mathrm{~h}$ in the teflon container to homogenize. After stirring, the Teflon containing mixture then was placed inside the hydrothermal vessel. The hydrothermal condition then was set at $160^{\circ} \mathrm{C}$ for $4 \mathrm{~h}, 24 \mathrm{~h}, 48 \mathrm{~h}$, and $72 \mathrm{~h}$ respectively. Hydrothermal treatment was performed by using SOP High- 
Pressure Autoclave Reactor. After hydrothermal treatment, the as-synthesized HAP was filtered and washed until the $\mathrm{pH}$ of the filtered water was neutral, thus removing the acid that was produced in this reaction. The as-synthesized powder was dried in an oven at $90^{\circ} \mathrm{C}$ for $24 \mathrm{~h}$. The dried powder was then characterized by X-ray diffraction, XRD (Bruker D2 Phaser), Scanning Electron Microscopy, SEM (Hitachi TM3000 Tabletop Microscope) and Transmission Electron Microscopy, TEM (Philip CM12).

\subsection{Fabrication of Porous BCP}

To fabricate porous BCP, initially $\mathrm{Mg}\left(\mathrm{NO}_{3}\right)_{2}$ was dissolved into $30 \mathrm{~mL}$ of distilled water and stirred for $10 \mathrm{~min}-$ utes. Subsequently, $10 \mathrm{~g}$ of the synthesized BCP powder was added slowly into $\mathrm{Mg}\left(\mathrm{NO}_{3}\right)_{2}$ solution to make a slurry. $\mathrm{Mg}\left(\mathrm{NO}_{3}\right)_{2}$ was added as the sintering aid to densify the porous BCP at relatively lower sintering temperature. A sponge template (polyurethane) was cut into $10 \mathrm{~mm} \times$ $20 \mathrm{~mm} \times 30 \mathrm{~mm}$ in size, and dipped into the slurry. To optimize the impregnation of slurry, the sponge template was squeezed at least ten times whilst dipping. After drying at $60^{\circ} \mathrm{C}$ for $2 \mathrm{~h}$, the sponge template with BCP slurry then were sintered in a furnace. The specimens were heated from room temperature to $500^{\circ} \mathrm{C}$ at $1{ }^{\circ} \mathrm{C} / \mathrm{min}$ for $2 \mathrm{~h}$ to burn out the sponge template, and then heated to $900^{\circ} \mathrm{C}$ at $5^{\circ} \mathrm{C} / \mathrm{min}$ for $2 \mathrm{~h}$ to sinter the ceramics.

\section{Results and Discussion}

\subsection{Characterization of BCP}

Figure 1 shows the X-ray diffraction patterns of as-synthesized powder obtained from the hydrothermal treatment. It is observed that $\beta$-TCP gradually transformed to HA phase with the longer time under hydrothermal condition. Transformation of $\beta$-TCP to HA phase can be explained through the following reaction (Equation (1)) [11]:

Initially, the reaction had transformed around $18 \mathrm{wt} \%$ of $\beta$-TCP into HA phase after hydrothermally treated for $4 \mathrm{~h}$ (calculated by Expert High Score Software). The transformation was indicated from the main peaks of $\beta$-TCP at the $2 \theta$ of $27.8^{\circ}, 31^{\circ}$ and $34.4^{\circ}$ which decreased and new peaks, assigned to the HA phase, at the $2 \theta$ of 31.7, 32.2 and 32.8 which appeared after hydrothermally treated for $4 \mathrm{~h}$ compared to the peaks from the untreated $\beta$-TCP powder (Figure 1). The transformation process was continued with longer treating time. The HA phase increased after being hydrothermally treated for $24 \mathrm{~h}$, followed by decreasing the $\mathrm{pH}$ of the solution (Table 1). After being treated at $48 \mathrm{~h}$, monetite $\left(\mathrm{CaHPO}_{4}\right)$ phase was produced besides HA and the remaining $\beta$-TCP phases, yielding triphasic powders. Monetite was formed due to the low $\mathrm{pH}$ value of the solution as phosphoric acid form, which later reacted with $\beta$-TCP. As $\mathrm{pH}$ rose, after hydrothermally treated for $72 \mathrm{~h}$, monetite was disappeared. Transformation of $\beta$-TCP to $\mathrm{CaHPO}_{4}$ occurred favorably through the following reaction [12]:

$$
\beta-\mathrm{Ca}_{3}\left(\mathrm{PO}_{4}\right)_{2}+\mathrm{H}_{3} \mathrm{PO}_{4} \rightarrow 3 \mathrm{CaHPO}_{4}
$$

Table 1 shows that more than half of the precursor had been transformed into $\mathrm{HA}$ and $\mathrm{CaHPO}_{4}$ after being hydrothermally treated for $48 \mathrm{~h}$. After hydrothermally treated for $72 \mathrm{~h}$, monetite had disappeared, yielding only HA and $\beta$-TCP phases. The result indicated that monetite had gradually transformed to HA phase with longer treating time. The transformation of monetite to HA phase proceeded through the following reaction (Equation (3)) [13]:

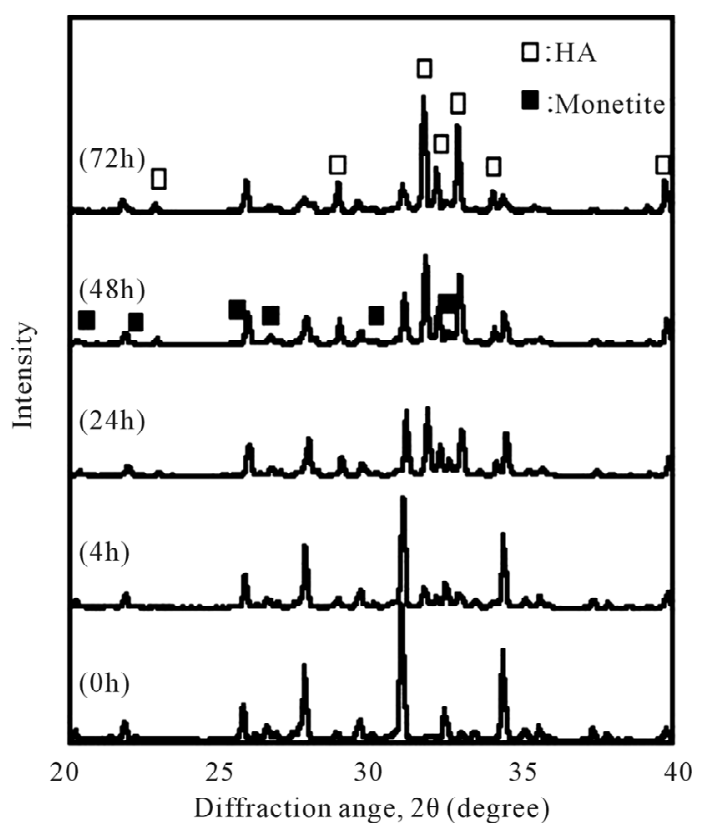

Figure 1. X-ray diffraction of $\beta$-TCP powder after being hydrothermally treated.

Table 1. Summary of the phase composition and $\mathrm{pH}$ of solution of the obtained BCP powder at different treating time.

\begin{tabular}{ccc}
\hline Treating time & Crystalline phase, wt $\%$ & pH of solution \\
\hline $4 \mathrm{~h}$ & $18.2 \%$ HA and $81.8 \% \beta$-TCP & 6.03 \\
$24 \mathrm{~h}$ & 45.3\% HA and $54.7 \% \beta$-TCP & 5.34 \\
$48 \mathrm{~h}$ & $\begin{array}{c}\text { 51.4\% HA, 42.5\% } \beta \text {-TCP and 6.1\% } \\
\text { CaHPO } 4\end{array}$ & 4.63 \\
$72 \mathrm{~h}$ & 75.9\% HA and 24.1\% $\beta$-TCP & 5.13 \\
\hline
\end{tabular}

$$
10 \beta-\mathrm{Ca}_{3}\left(\mathrm{PO}_{4}\right)_{2}+6 \mathrm{H}_{2} \mathrm{O} \rightarrow 3 \mathrm{Ca}_{10}\left(\mathrm{PO}_{4}\right)_{6}(\mathrm{OH})_{2}+2 \mathrm{H}_{3} \mathrm{PO}_{4}
$$




$$
10 \mathrm{CaHPO}_{4}+2 \mathrm{H}_{2} \mathrm{O} \rightarrow \mathrm{Ca}_{10}\left(\mathrm{PO}_{4}\right)_{6}(\mathrm{OH})_{2}+4 \mathrm{H}_{3} \mathrm{PO}_{4}(3)
$$

Up to this stage, $75.9 \mathrm{wt} \%$ of HA phase had been synthesized after $72 \mathrm{~h}$ of treating time. The increase of the HA composition in the BCP powder was followed by the decrease of the $\beta$-TCP peaks and the increase of the HA peaks in the XRD patterns with longer treating time (Figure 1). $\beta$-TCP had been incompletely transformed to HA, yielding biphasic phases of those compounds by the recent hydrothermal treatment. Moreover, gradual transformation of $\beta$-TCP to HA during hydrothermal reaction (which is time dependent) allows to control the composition of the BCP powder by manipulating the treating time. Controllable phase composition of BCP is an important factor to manipulate the resorbability of BCP. The resorbability of BCP depends on their HA $\beta$-TCP ratios, with the lower the ratio, the higher the resorbability [14].

Figure 2 shows the change of $\beta$-TCP powder morphology after being hydrothermally treated at $160^{\circ} \mathrm{C}$ for $72 \mathrm{~h}$. Initially, $\beta$-TCP powder was in near spherical shape before hydrothermal treatment (Figure 2(a)). The rodlike shape powder was then obtained after hydrothermal treatment for $72 \mathrm{~h}$ (Figure 2(b)), indicating that $\beta$-TCP has been transformed into HA powder. However, since $\beta$-TCP had remained, spherical powder, which is the $\beta$-TCP particles, was also observed. Hydrothermal reaction allows production of HA crystals with larger crystals in acidic condition. In this study, HA particles also tend to grow larger since the $\mathrm{pH}$ is in acidic condition as the result of phosphoric acid formation during reaction. Ac-

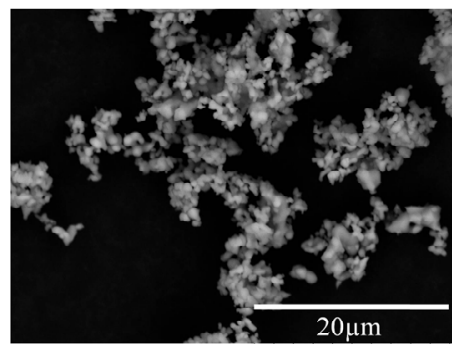

(a)

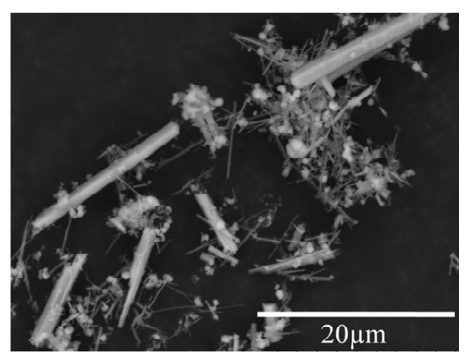

(b)

Figure 2. SEM images of $\beta$-TCP powder (a) and $\beta$-TCP after being hydrothermally treated for $72 \mathrm{~h}(\mathrm{~b})$. cording to SEM images (Figure 2(d)), it was found that HA particles were intimately mixed with the $\beta$-TCP particles, forming a BCP.

The $\beta$-TCP particles and as-synthesized particles obtained from the longer treating time (72 h) using TEM are shown in Figure 3. As seen, before being hydrothermally treated, $\beta$-TCP was in near spherical and irregular shape particles. These spherical and irregular shape particles then were transformed into rod-like shape HA particles under hydrothermal condition.

\subsection{Porous Sintered BCP}

The BCP powder obtained from the $\beta$-TCP phase transformation under hydrothermal condition was then preceded to porous scaffold by soaking in a template and then sintered. According to XRD patterns (Figure 4), it was observed that the $\beta$-TCP peaks were raised after sintering. It indicated that HA has decomposed and reformed into $\beta$-TCP phase during sintering.

Figure 5 shows the compositional change after sintering, where $\beta$-TCP phase raise from about $24 \%$ at the initial pre-sintering to $91 \%$ after sintering at $900^{\circ} \mathrm{C}$. Composition of HA phase reduced was due to the result of HA decomposition. Accordingly, HA phase was decomposed at a relatively low sintering temperature, indicated that it exists as calcium deficient HA. The excess of hydrogen $\left(\mathrm{H}^{+}\right)$ions in the solution from phosphoric acid were incorporated into HA lattice yielding calcium deficient HA [13]. Calcium deficient HA is decomposed through the following reaction (Equation (4)) [15]:

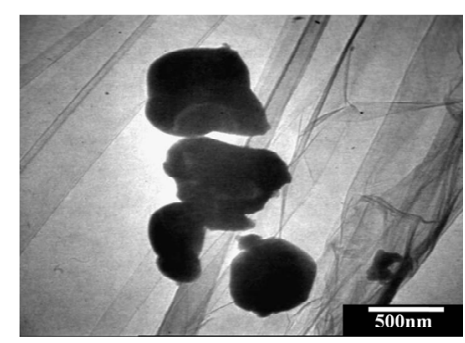

(a)

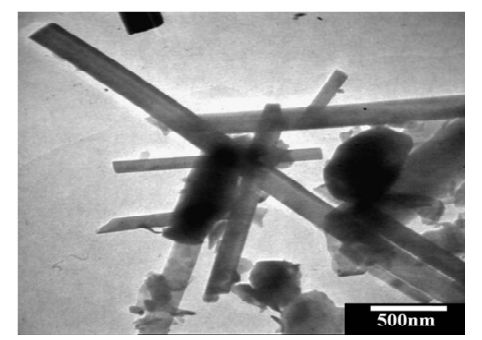

(b)

Figure 3. TEM images of $\beta$-TCP (a) and $\beta$-TCP after being hydrothermally treated for $72 \mathrm{~h}(\mathrm{~b})$.

$$
\mathrm{Ca}_{10-\mathrm{x}}\left(\mathrm{HPO}_{4}\right)_{\mathrm{x}}\left(\mathrm{PO}_{4}\right)_{6-\mathrm{x}}(\mathrm{OH})_{2-\mathrm{x}} \rightarrow(1-\mathrm{x}) \mathrm{Ca}_{10}\left(\mathrm{PO}_{4}\right)_{6}(\mathrm{OH})_{2}+3 \mathrm{x} \beta-\mathrm{Ca}_{3}\left(\mathrm{PO}_{4}\right)_{2}+\mathrm{xH}_{2} \mathrm{O}
$$




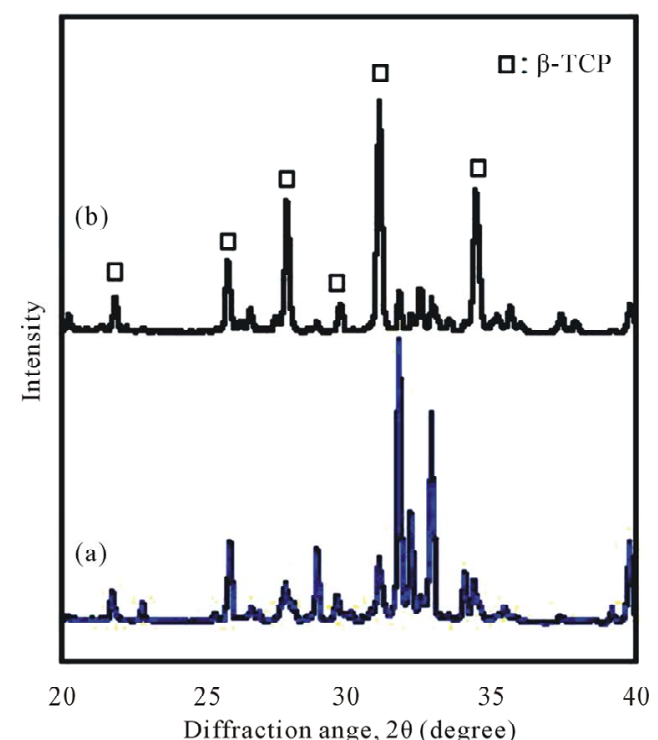

Figure 4. X-ray diffraction of synthesized BCP powder (a) and sintered BCP scaffold (b).

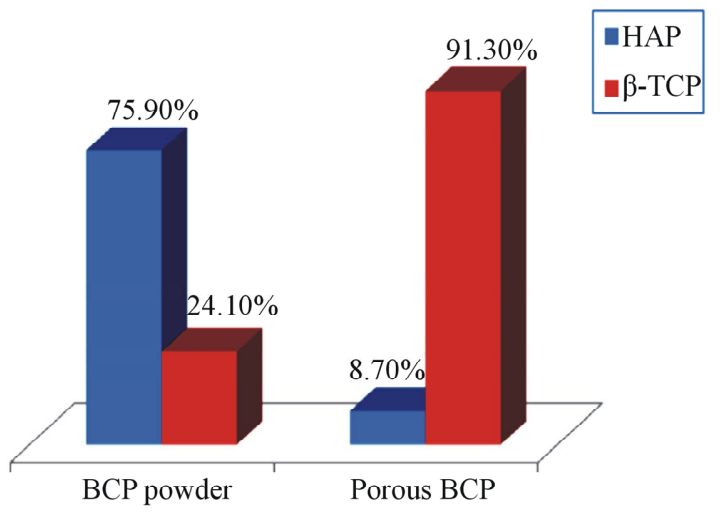

Figure 5. Phase composition of synthesized BCP powder and sintered BCP scaffold.

The decomposition of HA phase might also be due to the presence of $\mathrm{Mg}\left(\mathrm{NO}_{3}\right)_{2}$ in the BCP powder. $\mathrm{Mg}\left(\mathrm{NO}_{3}\right)_{2}$ was used as the sintering aid which would decompose into $\mathrm{MgO}$ at high temperature. However, the MgO peaks are not detected in the XRD patterns of the BCP scaffold (Figure 4), indicating that the free $\mathrm{MgO}$ was not presence in the $\mathrm{HA} / \beta$-TCP mixture. MgO is able to incorporate into either HA or $\beta$-TCP [16,17]. However, in this study, MgO was likely incorporated in the HA crystal since the HA composition was significantly reduced after sintering. It was reported that MgO-incorporated HA is not stable at high temperature, which would decompose into Mg-incorporated $\beta$-TCP [17]. Therefore, the decomposition of HA was accelerated with the presence of $\mathrm{Mg}\left(\mathrm{NO}_{3}\right)_{2}$, yielding a significant amount of $\beta$-TCP after sintering (Figure 5).

Stoichiometric HA and $\beta$-TCP produced after decomposition is confirmed in XRD result (Figure 4). Fur- thermore, $\beta$-TCP phase existed in the initial powder may accelerate the decomposition of HA phase during sintering due to intimate contact of the BCP powders as observed in Figure 3(b) [15]. The porous product obtained from the BCP powder actually was still in biphasic form. Although, its composition has changed due to sintering, with formation of higher $\beta$-TCP, thus would mean that the resorbability rate would be increased.

Porous BCP obtained from this study, still preserved morphology of the sponge template with the spherical pores $(\sim 500 \mu \mathrm{m})$ as observed in Figures 6(a) and (b), and

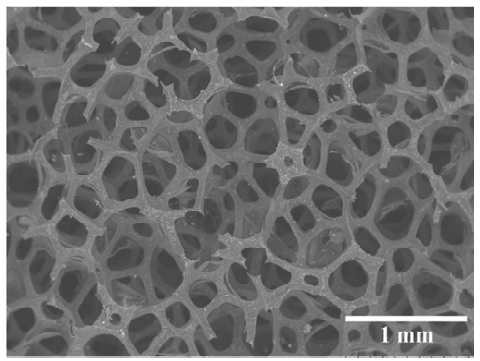

(a)

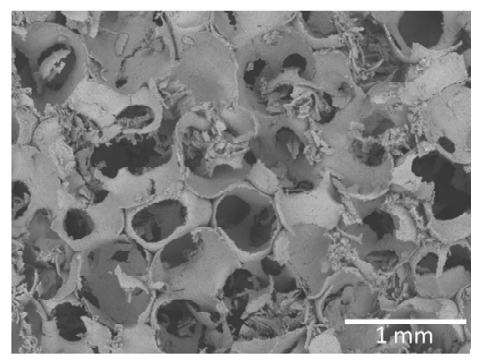

(b)

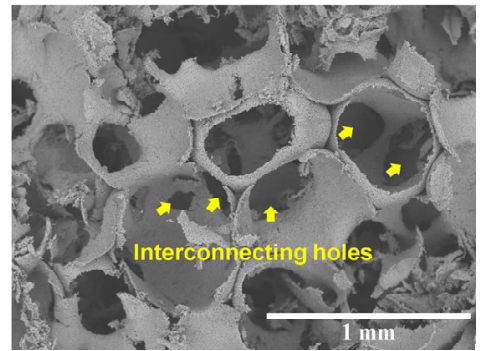

(c)

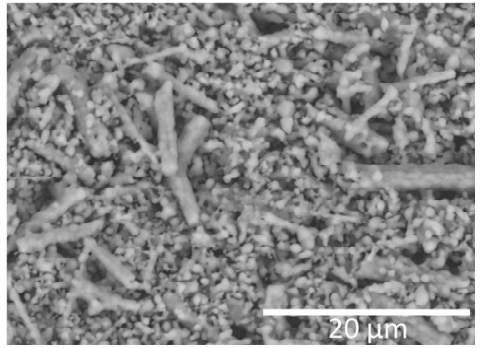

(d)

Figure 6. Morphology of porous BCP: (a) sponge template, (b) macropores, (c) interconnecting holes and (d) micropores. 
possesses relatively homogenous pores structure with the holes, which lie in the interpores (Figure 6(c)). These interpore holes perhaps would lead to the formation of the interconnected porous structure throughout the porous body. It was reported that pores size bigger than 300 $\mu \mathrm{m}$ possessed greater cells ingrowth, yielding rapid tissue formation [18]. The obtained porous BCP also possessed micropores $(0.1-10 \mu \mathrm{m})$ which would enable nutrients to reach the cells via newly formed blood vessels for new bone formation. Micropores structure also has been reported to be responsible for osteoinductive property of bone substitute material [19].

After sintering, it seems that the morphology of HA particles has changed. Although has been decomposed, but, as observed, it still maintains their initial rod-like shape. It is observed that the rod-like shapes after sintering are actually composed of small granule-like shape (Figure 6(d)). These small granule-like shapes are $\beta$ TCP as the main composition of porous biphasic obtained after sintering. This morphology may lead to the different properties when the material is implanted to the living tissue. However, further study must be conducted to investigate the effect of this morphology.

\section{Conclusion}

Biphasic powders with HA and $\beta$-TCP have been successfully synthesized by a simple hydrothermal route using $\beta$-TCP powder. It was found that rod-like shape HA particles were yielded in this study. It was also observed that HA phase in BCP obtained under hydrothermal treatment was decomposed significantly when sintered at $900^{\circ} \mathrm{C}$ to produce BCP scaffold. The obtained porous BCP possessed both ideal macropores and micropores structure by which new bone formation could be effectively grown.

\section{Acknowledgements}

We acknowledge AUN/SEED-Net JICA for financial support and Universiti Sains Malaysia for the facility.

\section{REFERENCES}

[1] S. H. Kwon, Y. K. Jun, S. H. Hong and H. E. Kim, “Synthesis and Dissolution Behavior of $\beta$-TCP and HA $/ \beta$-TCP Composite Powders," Journal of the European Ceramic Society, Vol. 23, No. 7, 2003, pp. 1039-1045. doi:10.1016/S0955-2219(02)00263-7

[2] S. Kannan and J. M. F. Ferreira, "Synthesis and Thermal Stability of Hydroxyapatite- $\beta$-Tricalcium Phosphate Composites with Cosubstituted Sodium, Magnesium and Fluorine," Chemistry of Materials, Vol. 18, No. 1, 2006, pp. 198-203. doi:10.1021/cm051966i

[3] J. S. Cho, Y. N. Ko, H. Y. Koo and Y. C. Kang, "Synthesis of Nano-Sized Biphasic Calcium Phosphate Ceramics with Spherical Shape by Flame Spray Pyrolysis,” Journal of Materials Science: Materials in Medicine, Vol. 21, No. 4, 2010, pp. 1143-1149. doi:10.1007/s10856-009-3980-1

[4] E. Caroline Victoria and F. D. Gnanam, "Synthesis and Characterisation of Biphasic Calcium Phosphate,” Trends in Biomaterials \& Artificial Organs, Vol. 16, No. 1, 2002, pp. 12-14.

[5] H. Rojbani, M. Nyan, K. Ohya and S. Kasugai, "Evaluation of the Osteoconductivity of $\alpha$-Tricalcium Phosphate, $\beta$-Tricalcium Phosphate, and Hydroxyapatite Combined with or without Simvastatin in Rat Calvarial Defect," Journal of Biomedical Materials Research Part A, Vol. 98, No. 4, 2011, pp. 488-498. doi:10.1002/jbm.a.33117

[6] H. S. Ryu, K. S. Hong, J. K. Lee, D. J. Kim, J. H. Lee, B. S. Chang, D. H. Lee, C. K. Lee and S. S. Chung, "Magnesia-Doped HA $/ \beta$-TCP Ceramics and Evaluation of Their Biocompatibility,” Biomaterials, Vol. 25, No. 3, 2004, pp. 393-401. doi:10.1016/S0142-9612(03)00538-6

[7] X. Yang and Z. Wang, "Synthesis of Biphasic Ceramics of Hydroxyapatite and $\beta$-Tricalcium Phosphate with Controlled Phase Content and Porosity,” Journal of Materials Chemistry, Vol. 8, No. 10, 1998, pp. 2233-2237.

doi:10.1039/a802067a

[8] D. Daculsi, O. Laboux, O. Malard and P. Weiss, "Current State of the Art of Biphasic Calcium Phosphate Bioceramics," Journal of Materials Science: Materials in Medicine, Vol. 14, No. 3, 2003, pp. 195-200. doi:10.1023/A:1022842404495

[9] M. Yoshimura, H. Suda, K. Okamoto and K. Ioku, "Hydrothermal Synthesis of Biocompatible Whiskers," Journal of Materials Science, Vol. 29, No. 13, 1994, pp. 33993402. doi:10.1007/BF00352039

[10] H. Wakae, A. Takeuchi, K. Udoh, S. Matsuya, M. L. Munar, R. Z. LeGeros, A. Nakasima and K. Ishikawa, "Fabrication of Macroporous Carbonate Apatite Foam by Hydrothermal Conversion of $\alpha$-Tricalcium Phosphate in Carbonate Solutions," Journal of Biomedical Materials Research Part A, Vol. 87A, No. 4, 2008, pp. 957-963. doi:10.1002/jbm.a.31620

[11] O. V. Sinitsyna, A. G. Veresov, E. S. Kovaleva, Yu. V. Kolen'ko, V. I. Putlyaev and Yu. D. Tretyakov, "Synthesis of Hydroxyapatite by Hydrolysis of $\alpha-\mathrm{Ca}_{3}\left(\mathrm{PO}_{4}\right)_{3}$," Russian Chemical Bulletin, International Edition, Vol. 54, No. 1, 2005, pp. 79-86.

[12] L. G. Galea, M. Bohner, J. Lemaitre, T. Kohler and R. Muller, "Bone Substitute: Transforming $\beta$-Tricalcium Phosphate Porous Scaffolds into Monetite,” Biomaterials, Vol. 29, No. 24-25, 2008, pp. 3400-3407. doi:10.1016/j.biomaterials.2008.04.041

[13] A. Ito and K. Onuma, "Growth of Hydroxyapatite Crystals,” In: K. Byrappa and T. Ohachi, Eds., Crystal Growth Technology, William Andrew, Inc., New York, 2003, pp. 525-559. doi:10.1016/B978-081551453-4.50018-X

[14] G. Daculsi, R. Z. LeGeros, E. Nery, K. Lynch and B. Kerebel, "Transformation of Biphasic Calcium Phosphate Ceramics in Vivo: Ultrastructural and Physicochemical Characterization," Journal of Biomedical Materials Research Part A, Vol. 23, No. 8, 1989, pp. 883-894.

doi:10.1002/jbm.820230806 
[15] R. W. N. Nilen and P. W. Richter, “The Thermal Stability of Hydroxyapatite in Biphasic Calcium Phosphate Ceramics," Journal of materials Science: Materials in Medicine, Vol. 19, No. 4, 2008, pp. 1693-1702. doi:10.1007/s10856-007-3252-X

[16] H. S. Ryu, K. S. Hong, J. K. Lee, D. J. Kim, J. H. Lee, B. S. Chang, D. H. Lee, C. K. Lee and S. S. Chung, "Magnesia-Doped HA $/ \beta$-TCP Ceramics and Evaluation of Their Biocompatibility,” Biomaterials, Vol. 25, No. 3, 2004, pp. 393-401. doi:10.1016/S0142-9612(03)00538-6

[17] A. Bigi, G. Falini, E. Foresti, M. Gazzano, A. Ripamonti and N. Roveri, "Magnesium Influence on Hydroxyapatite Crystallization," Journal of Inorganic Biochemistry, Vol.
49, No. 1,1993 , pp. 69-78. doi:10.1016/0162-0134(93)80049-F

[18] S. Yang, K. F. Leong, Z. Du and C. K. Chua, “The Design of Scaffolds for Use in Tissue Engineering. Part I. Traditional Factors,” Tissue Engineering, Vol. 7, No. 6, 2001, pp. 679-689. doi:10.1089/107632701753337645

[19] H. Yuan and K. Groot, "Calcium Phosphate Biomaterials: An Overview,” In: R. L. Reis and S. Weiner, Eds., Learning from Nature How to Design New Implantable Biomaterialsis: From Biomineralization Fundamentals to Biomimetic Materials and Processing Routes, Springer, Amsterdam, 2005, pp. 37-57. doi:10.1007/1-4020-2648-X_3 